\title{
NEW RECORD OF ELONGATE LANTERNFISH, NOTOSCOPELUS ELONGATUS (COSTA, 1844), FROM THE COASTAL WATERS OF AEGEAN SEA, TURKEY, WITH NOTES ON SPECIES' MORPHOLOGY AND DISTRIBUTION
}

\author{
Sezginer TUNCER ${ }^{1}$, Alexei ORLOV ${ }^{2 *}$, Ozcan OZEN $^{1}$, and Sabri BILGIN ${ }^{1}$ \\ ${ }^{1}$ Faculty of Fisheries, Canakkale Onsekiz Mart University, Canakkale, Turkey \\ ${ }^{2}$ Department of International Fisheries Cooperation, Russian Federal Research Institute of Fisheries \\ and Oceanography, Moscow, Russia
}

\begin{abstract}
Tuncer S., Orlov A., Ozen O., Bilgin S. 2009. New record of elongate lanternfish, Notoscopelus elongatus (Costa, 1844), from the coastal waters of Aegean Sea, Turkey, with notes on species' morphology and distribution. Acta Ichthyol. Piscat. 39 (2): 139-145.
\end{abstract}

Background. Marine ichthyofauna of the Mediterranean Sea is represented by 712 species, 117 of which are deepwater fishes. During the last decade, this ichthyofauna has been considerably enriched, either by Suez Canalor Strait of Gibraltar migrations or simply by mariculture escapees. This study is intended to discussed morphology of one of such non-indigenous fish species and its distribution.

Materials and Methods. Three specimens of elongate lanternfish, Notoscopelus elongatus (Costa, 1844), were captured during a commercial lift net operation in Ece Limani, Aegean Sea, Turkey. The fish were described and illustrated, following commonly accepted procedures.

Results. This is the first documented new record of the species from Aegean Sea, Turkey. The described meristic and morphometric features of elongate lanternfish, Notoscopelus elongatus, are consistent with the data provided by descriptors of its previous findings (with minor exceptions). The most interesting morphological feature of the presently described material is the presence in the smaller specimen (TL $103 \mathrm{~mm}$ ) of 4 precaudal photophores (Prc) on the left body side (in contrast to 3 usual ones).

Conclusion. This work will undoubtedly enhance our knowledge on newly introduced species on lanterfishes in the Mediterranean and in Aegean Sea in particular.

Keywords: elongate lanternfish, Notoscopelus elongatus, Aegean Sea, Turkey

\section{INTRODUCTION}

The marine ichthyofauna in the Mediterranean Sea is highly rich and diverse and, according to FishBase (Froese and Pauly 2009), it is represented by 712 species, 117 of which are deepwater fishes. During the last decade, Mediterranean fish fauna as a whole and that of the Aegean Sea in particular has been considerably enriched (Taşkavak et al. 2000, Filiz et al. 2007, Corsini-Foka and Economidis 2007). This process takes place by means of several ways: via Lessepsian migrants penetrating from the Red Sea through Suez channel (Bilecenoglu et al. 2002a, 2006a, Corsini et al. 2005, Kasapidis et al. 2007), via migrants from the Atlantic Ocean through Strait of Gibraltar and via marine aquaculture (CorsiniFoka and Economidis 2007, Filiz et al. 2007). Ichthyofauna of the northern Mediterranean can be enriched furthermore by means of range extension of species, inhabiting coastal waters of the northern Africa (Corsini-Foka and Frantzis 2009), likely due to climatic changes (warming).
New findings of deepwater (Bilecenoglu et al. 2006b, Aydin et al. 2009, Filiz et al. 2007, Özaydin et al. 2007) and inshore (Ozen et al. 2007, 2009) species contribute to enrichment of the Turkish marine ichthyofauna considerably. The main reasons of recently increasing new records are associated with more extensive fishing efforts, development of deepwater fishery, and intensification of scientific research in the area (Filiz et al. 2007).

The family of lanternfishes (Myctophidae) is represented in the global oceans by almost 250 species, belonging to more than 30 genera (Froese and Pauly 2009) and is one of the largest families among bony fishes (Bekker 1983). Lanternfishes are widely distributed in all world oceans, occurring from the Arctic off Spitsbergen and northern Bering Sea to Antarctic ice shelves (Shust and Orlov 2003). There are 19 myctophid species known from the Mediterranean Sea (Froese and Pauly 2009), 14 of which occur in Turkish waters (Bekker 1983). The genus Notoscopelus is represented in the Mediterranean by two

\footnotetext{
${ }^{*}$ Correspondence: Dr. Alexei M. Orlov, Russian Federal Research Institute of Fisheries and Oceanography (VNIRO), 17, V. Krasnoselskaya, Moscow, 107140, Russia, phone: +7(499)2649143, fax: +7(499)2649021, e-mail: orlov@vniro.ru or orlovniro@yahoo.com
} 
species $N$. bolini and $N$. elongatus. Representatives of this genus might be distinguished from congeners by following characters: $\mathrm{AOa}_{1}$ is not elevated, Pol are placed in horizontal line, males have large supracaudal and small infracaudal glands, females bear small caudal glands, dorsal fin base is much longer as compared to anal fin base, 3 Prc (rare 4), distance $\operatorname{Prc}_{2-3}$ much larger than $\operatorname{Prc}_{1-2}$ (Bekker 1983). Both Mediterranean Notoscopelus species differed one from another by the number of gill rakers on the first gill arch; 26-28 (29) in N. bolini vs. 24 (23-25) in $N$. elongatus (see: Nafpaktitis 1975). The former species is distributed in the North Atlantic and the entire Mediterranean Sea (Nafpaktitis 1975). It was believed for a long time that the latter species inhabited exclusively the western part of the Mediterranean and that its distribution range reached as Far East as the Strait of Messina (Bini 1970). Recent publications report on the occurrence of $N$. elongatus within Greek waters of the Aegean Sea and in the Sea of Marmara (Labropoulou and Papaconstantinou 2000, Bilecenoglu et al. 2002b, Fricke et al. 2007). Nevertheless, none of these papers provides the data on capture localities, capture depths, sizes of fish, morphological characters, etc.

\section{MATERIAL AND METHODS}

In April 2009, three specimens of Notoscopelus elongatus were caught in Turkish waters of the north-eastern Aegean Sea. The objective of this study is to further document the easternmost record of $N$. elongatus for the Aegean Sea and for Turkish marine ichthyofauna and to provide some morphometric and meristic data on this endemic to the Mediterranean fauna species (Froese and Pauly 2009).
RESULTS (Taxonomic account)

Notoscopelus elongatus (Costa, 1844)

Synonyms:

Scopelus elongatus Costa, 1844

Scopelus pseudocrocodilus Moreau, 1891

Myctophum elongatum Brauer, 1904

Lampanyctus elongatus Tåning, 1918

Notoscopelus elongatus Bolin, 1959

Notoscopelus elongatus elongatus Nafpaktitis, 1975

Material examined. Three specimens: female 108 $\mathrm{mm}$ total length (TL), female $126 \mathrm{~mm}$ TL, and female 103 mm TL. All specimens were caught on 19 April 2009 during a commercial lift net operation targeting European pilchard, Sardina pilchardus, in the Ece Limani (lat $40^{\circ} 22^{\prime} 11^{\prime \prime} \mathrm{N}$, long $26^{\circ} 19^{\prime} 16^{\prime \prime} \mathrm{E}$ ), north-eastern Aegean Sea, Turkey (Fig. 1) at a depth of about $30 \mathrm{~m}$ at night. Specimens are deposited at Piri Reis Marine Museum, Canakkale Onsekiz Mart University, Canakkale, Turkey, under catalogue number PRM-PIS 2009-0063.

Diagnosis. Body elongate and slightly compressed (Fig. 2). Maximum body depth $18.4 \%-22.6 \%$ (mean $=20.7 \%)$ of standard length (SL); head length $23.6 \%-28.2 \%$ $($ mean $=26.1 \%)$ of SL; eye diameter $24.2 \%-27.8 \%$ $($ mean $=26.3 \%)$ of head length (Table 1$)$. Maxilla extending far beyond posterior margin of eye. Dorsal fin longer than anal fin. Distance from anal fin origin to caudal fin base equal or nearly equal to distance from rear eye margin to anal fin origin. Insertion of dorsal fin much nearer to snout than to caudal fin origin. Anal fin originating a little behind the middle of dorsal fin. Pectoral fins short, barely reaching origin of pelvic fins. Scales large, cycloid and deciduous as in most Myctophidae.

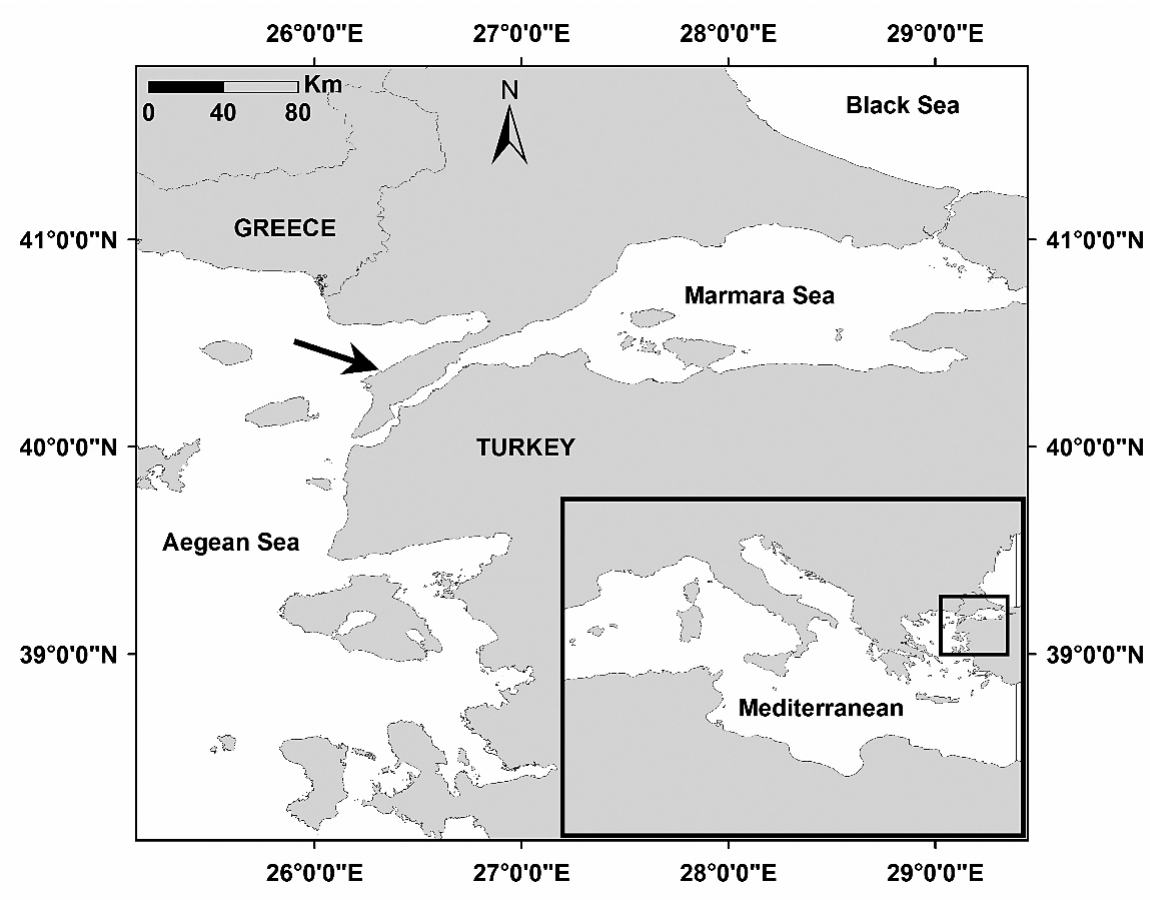

Fig. 1. Map showing the locality of Notoscopelus elongatus capture site in the northeastern Aegean Sea, Turkey; arrow indicates the locality of Eco Limani 
Dn well developed, consisting of a dorsal, small component in contact with a much larger ventral one extending along anterodorsal margin of orbit. Vn small, lying deep between olfactory organ and anterior margin of orbit. $\mathrm{PVO}_{2}$ above pectoral fin base. $5 \mathrm{PO}$, in a $1+3+1$ arrangement, with $\mathrm{PO}_{5}$ abruptly displaced dorsolateraly. $5 \mathrm{VO}$, with $\mathrm{VO}_{5}$ sometimes distinctly raised. SAO forming a very obtuse angle. AO $9+6-7$, total 15-16. Pol 2, horizontally arranged. $3-4$ Prc, in a $2-3+1$ arrangement. Patches of luminous tissue on trunk and at bases of procurrent caudal fin rays.

Dorsal fin rays 21; anal fin rays 18-19; pectoral fin rays $12-13$; pelvic fin rays 8 ; procurrent caudal fin rays 9 (dorsal) +10 (ventral), stiff, spine-like. Lateral line pores 43-46; vertebrae 38 (Table 1).

\section{DISCUSSION}

Most of the morphological characters of our specimens of elongate lanternfish agree well with previous descriptions of various material collected in the western Mediterranean (Bolin 1959, Bini 1970, Nafpaktitis 1975, Nafpaktitis et al. 1977, Palomera 1983, Hulley 1984, Costa and Genovese 2009) with minor exceptions. Our specimens differ from those caught in the Strait of Messina (Costa and Genovese 2009) in pectoral fin rays counts (12-13 vs. 10-12). Adults of this species are characterized by 12-13 (Bini 1970, Nafpaktitis 1975, Nafpaktitis et al. 1977, Hulley 1984) or 12-14 (Lo Bianco 1931-1956) pectoral fin rays. Costa and Genovese (2009) most likely examined not only adult but larval characteristics as well. At is well known (Palomera 1983, Costa 1999) counts of fin rays in larvae are considerably less than those in adults.
The majority of differences resulted when comparing original description based on specimen caught off Naples (Costa 1844) with our specimens and published data. The type material had 22 dorsal fin rays (vs. 21 dorsal fin rays in all our specimens) that is typical for Mediterranean N. elongatus; 21 and 23 (Bini 1970, Nafpaktitis 1975, Nafpaktitis et al. 1977, Hulley 1984) or 24 (Lo Bianco 1931-1956) occasionally occur. The anal, pelvic, and caudal fin rays were 16,11 , and 18 respectively which does not correspond to the known meristic data of species under consideration. Thus, according to available data, numbers of rays in anal, pelvic, and caudal fins are 18-19, 8, and 19, respectively (Nafpaktitis 1975, Nafpaktitis et al. 1977, Hulley 1984, and presently reported data). Lo Bianco (1931-1956) and Bini (1970) noted that the number of anal fin rays might vary between 17 and 20 . The reasons of these differences are not clear and are likely related to the accuracy of counts made during original description. Initial counts may not be re-examined since type specimen is unknown (Eschmeyer 1998).

There are controversial data on the number of lateral line scales. Nafpaktitis (1975) and Nafpaktitis et al. (1977) noted 42-43 scales, while Lo Bianco (1931-1956) and Costa and Genovese (2009) indicated 39-42 scales in lateral line. We could not count the lateral line scales, since elongate lanternfish has deciduous scale typical for most myctophids. The number of pores in lateral line that were counted in the present study (43-46) is slightly higher than published data on number of scales, a fact most likely associated with extending of lateral line to head region, beyond scales.

The most interesting morphological feature of our material is the presence in the smaller specimen (TL $103 \mathrm{~mm}$ )

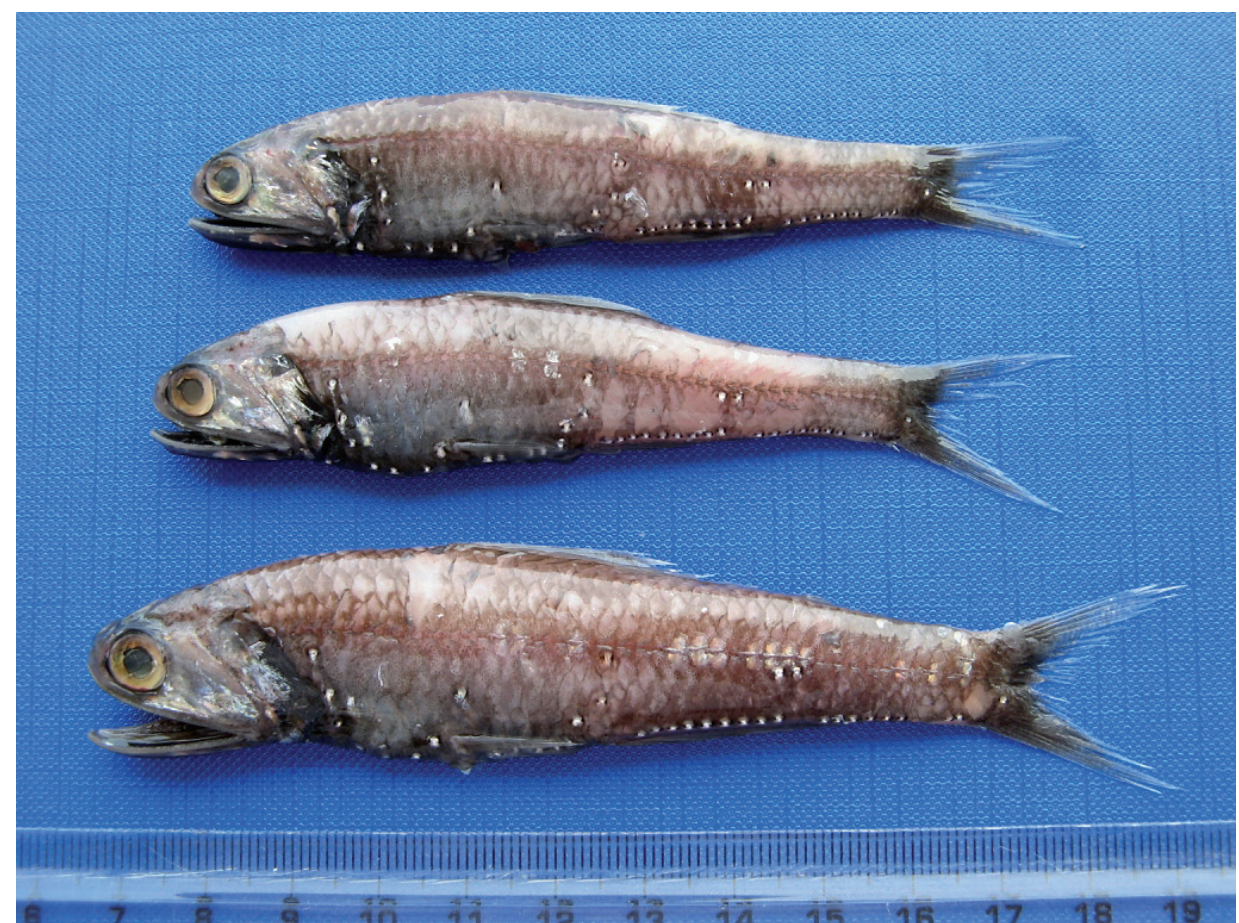

Fig. 2. Specimens of Notoscopelus elongatus (PRM-PIS 2009-0063) caught in the northeastern Aegean Sea, Turkey 
Some morphometric and meristic data for three specimens of Notoscopelus elongatus (all females) caught in the Ece Limani, Aegean Sea, Turkey

\begin{tabular}{|c|c|c|c|c|c|}
\hline & \multirow{2}{*}{ Character } & \multicolumn{4}{|c|}{ Specimen } \\
\hline & & $\# 1$ & $\# 2$ & \#3 & Mean \\
\hline \multirow{5}{*}{ 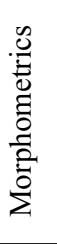 } & Total length [mm] & 108 & 126 & 103 & 112.3 \\
\hline & Standard length [mm] & 91 & 105 & 84 & 93.3 \\
\hline & Maximum body depth [\% of SL] & 22.6 & 18.4 & 21.8 & 20.9 \\
\hline & Head length [\% of SL] & 26.4 & 23.6 & 28.2 & 26.1 \\
\hline & Eye diameter [\% of head length] & 27.0 & 27.8 & 24.2 & 26.3 \\
\hline \multirow{8}{*}{ 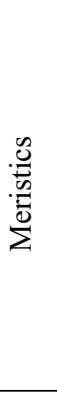 } & Dorsal fin rays & 21 & 21 & 21 & 21.0 \\
\hline & Anal fin rays & 18 & 19 & 19 & 18.7 \\
\hline & Pelvic fin rays & 8 & 8 & 8 & 8.0 \\
\hline & Pectoral fin rays & 13 & 12 & 13 & 12.7 \\
\hline & Caudal fin rays (total) & $9+10(19)$ & $9+10(19)$ & $9+10(19)$ & $9+10(19)$ \\
\hline & Gill rakers (total) & $7+1+16(24)$ & $7+1+16(24)$ & $7+1+16(24)$ & $7+1+16(24)$ \\
\hline & Lateral line pores & 43 & 44 & 46 & 44.3 \\
\hline & Number of vertebrae & 38 & 38 & 38 & 38.0 \\
\hline \multirow{7}{*}{ 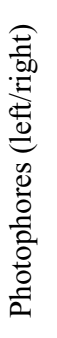 } & $\mathrm{PO}$ & $5 / 5$ & $5 / 5$ & $5 / 5$ & $5 / 5$ \\
\hline & VO & $5 / 5$ & $5 / 5$ & $5 / 5$ & $5 / 5$ \\
\hline & $\mathrm{AOa}$ & $9 / 9$ & $9 / 9$ & $9 / 9$ & $9 / 9$ \\
\hline & $\mathrm{AOp}$ & $7 / 6$ & $6 / 7$ & $6 / 7$ & $6.3 / 6.7$ \\
\hline & Prc (arrangement) & $3(2+1) / 3(2+1)$ & $3(2+1) / 3(2+1)$ & $4(3+1) / 3(2+1)$ & $3.3(2.3+1) / 3.0(2+1)$ \\
\hline & $\mathrm{SAO}$ & $3 / 3$ & $3 / 3$ & $3 / 3$ & $3 / 3$ \\
\hline & Pol & $2 / 2$ & $2 / 2$ & $2 / 2$ & $2 / 2$ \\
\hline
\end{tabular}

of 4 precaudal photophores (Prc) on the left body side. Typically all representatives of the genus Notoscopelus are characterized by 3 Prc arranged as $2+1$ (Nafpaktitis 1975). However, this is not a unique case since it has been previously referred in the literature (Tåning 1918, 1928, 1932, Lo Bianco 1931-1956) but later was not taken in account by Nafpaktitis (1975) in his review of the genus Notoscopelus.

We also observed variations in the number of AOp in each individual specimen examined (6-7 on different sides of the body). Previously, such variations in this species were not described but are known for other representatives of the family (Kobayashi 1958, Kubota and Uyeno 1972).

Comparison of our data with those published by Tåning $(1918,1928,1932)$ showed considerable differences in most characters examined. The analysis of those data showed that the material was collected not only in Mediterranean but also in the North Atlantic and may represent combination of more than one species and hence was not included herein.

Interestingly, our samples are composed of females only. Life history of elongate lanternfish is poorly understood. However, sexual dimorphism in growth rate, size of maturation, and longevity and predomination of females in older age classes are known for congeneric species Notoscopelus kröyeri (see: Filin 1989, Manzhirina and Filin 1992). Females of N. elongatus may also attain older age and larger sizes as compared to males. We speculate that this fact might explain why our samples contain females only.

Data on maximum size of $N$. elongatus is rather controversial. Nafpaktitis (1975) noted that $N$. elongatus is characterized by smaller sizes as compared to $N$. kröyeri. The longest specimen he examined was a $98 \mathrm{~mm}$ long female with small granular ovaries (Nafpaktitis et al. 1977). Hulley (1984) reported a maximum length of $106 \mathrm{~mm}$. The largest size of species considered $(150 \mathrm{~mm})$ can be found in monographs of Lo Bianco (1931-1956) and likely followed by Bini (1970) who also indicated $150 \mathrm{~mm}$ as maximum length of elongate lanternfish. We incline to consider $150 \mathrm{~mm}$ as erroneous value since E. Tortonese was both the author of chapter describing $N$. elongatus in the monograph edited by Lo Bianco (1931-1956) and subsequently one of the editors of the book with chapter written by Hulley (1984), who recorded a maximum length of $106 \mathrm{~mm}$. Our largest specimen is $126 \mathrm{~mm} \mathrm{TL}$ and this should be considered as the biggest documented size of species under question.

Distribution. Geographic distribution of Notoscopelus elongatus is a complicated and controversial issue that is mainly associated with the uncertain taxonomic status of the species and respective incorrectness of its range definition for many years. $N$. elongatus was described for the first time from the waters off Naples 
(Costa 1844). Subsequently, Tåning (1918) suggested that this species inhabits Mediterranean Sea and Atlantic Ocean from Greenland to Cape of Good Hope in South Africa. Later, the same author (Tåning 1928, 1932) restricted the species' distribution range within the Mediterranean and North Atlantic only, as far north as Norway, Iceland, and Greenland. Lo Bianco (1931-1956) noted that $N$. elongatus in spite of Mediterranean Sea and the Atlantic Ocean occurs as well in the Pacific Ocean and Antarctic seas. Restriction of the distribution range of the species in the Mediterranean Sea only appeared in the middle of last century (Bolin 1959). In this regard suggestions of Nafpaktitis (1975) and Nafpaktitis et al. (1977) regarding species' range seem a bit confusing. In the first paper (Nafpaktitis 1975) the range of N. elongatus is limited in the western Mediterranean only while in the latter publication (Nafpaktitis et al. 1977) both the Atlantic and Mediterranean distribution was noted. In our opinion, these contradictions are associated mostly with changes in the taxonomic status of the species under consideration since it has been placed from species to subspecies level and vice versa. Since all the Atlantic representatives of the genus Notoscopelus are characterized by similar morphological pattern, the elongate lanternfish could be considered by some authors as a combination of two or more different species ( $N$. elongatus, $N$. resplendens, and N. kröyeri) (see: Nafpaktitis 1975).

Currently, the overwhelming majority of researchers, following Bolin (1959), believe that $N$. elongatus is an endemic of the Mediterranean (Bini 1970, Bekker 1983, Hulley 1984). It is most abundant in the western part of the sea (Bekker 1983, Moreno-Amich and Garcia-Berthou 1985, Sabatés 1990, Sabatés and Masó 1992, Morales-Nin et al. 2001, Sabatés et al. 2007, Fricke et al. 2007) and occurs as far east as the Strait of Messina (Bini 1970, Costa 1999). However, recently $N$. elongatus was discovered off the Canary Islands. This record was represented by juveniles 19-31 mm SL (voucher specimens exist) and most likely is the result of transportation of larvae from the Mediterranean to Atlantic Ocean by eddies (Wienerroither 2005). The presence of elongate lanternfish in the Greek waters of the Aegean Sea was noted by Labropoulou and Papaconstantinou (2000) but there are no voucher specimens that could be used for confirmation. Occurrence of $N$. elongatus in Turkish waters was also noted by Bilecenoglu et al. (2002b) and Fricke et al. (2007), yet remarks in latter paper are slightly controversial. These authors reported the presence of the species in the Sea of Marmara, but are not sure of its occurrence in the Mediterranean and Aegean Sea („Possibly also Aegean Sea and Mediterranean Sea area,", P. 61). Moreover, no voucher specimens that confirm occurrence of $N$. elongatus in Turkish waters exist (Murat Bilecenoglu, pers. comm.). Therefore our capture may be considered as the easternmost documented record of the species. Thus, the known range of $N$. elongatus extends from off Canary Islands to Turkish coastal waters of the Aegean Sea.

\section{ACKNOWLEDGEMENTS}

We would like to thank Prof. Francesco Costa (Department of Animal Biology and Marine Ecology, University of Messina, Messina, Italy) and Mysi Hoang (Department of Ichthyology, California Academy of Sciences, San Francisco, USA) who kindly provided us with some rare and old publications. Thanks to Kepez Balıkçılık for providing the specimens.

\section{REFERENCES}

Aydin İ., Akçinar S.C., Soykan O. 2009. First record of pignosed arrowtooth eel, Dysomma brevirostre (Actinopterygii: Anguilliformes: Synaphobranchidae), from the Aegean Sea. Acta Ichthyologica et Piscatoria 39: 51-53. DOI: 10.3750/AIP2009.39.1.10.

Bekker V.E. 1983. [Myctophid fishes of the world oceans.] Nauka, Moskva. [In Russian.]

Bilecenoglu M., Kaya M., Akalin S. 2006a. Range expansion of silverstripe blaasop, Lagocephalus sceleratus (Gmelin, 1789), to the northern Aegean Sea. Aquatic Invasions 1: 289-291. DOI: 10.3391/ai.2006.1.4.14.

Bilecenoglu M., Kaya M., Irmak E. 2006b. First record of the slender snipe eel, Nemichthys scolopaceus (Nemichthyidae), and the robust cusk-eel, Benthocometes robustus (Ophidiidae), from the Aegean Sea. Acta Ichthyologica et Piscatoria. 36: 85-88.

Bilecenoglu M., Taskavak E., Kunt K.B. 2002a. Range extension of three Lessepsian migrant fish (Fistularia commersoni, Sphyraena flavicauda, Lagocephalus suezensis) in the Mediterranean Sea. Journal of the Marine Biological Association of the United Kingdom 82: 525-526. DOI: $10.1017 / \mathrm{S} 0025315402005829$.

Bilecenoglu M., Taskavak E., Mater S., Kaya M. 2002 b. Checklist of the marine fishes of Turkey. Zootaxa 113: $1-194$.

Bini G. 1970. Atlante dei pesci delle coste Italiane. [Atlas of fishes of the Italian coast.] Vol. 2. Mondo Sommerso, Milano. [In Italian.]

Bolin R. 1959. Iniomi. Myctophidae from the „Michael Sars“ North Atlantic deep-sea expedition 1910. Report on the Scientific Results of the „Michael Sars“ North Atlantic Deep-Sea Expedition 19104 (pt.2)(7): 1-45.

Brauer A. 1904. Die Gattung Myctophum. Zoologischer Anzeiger 28: 377-404.

Corsini M., Margies P., Kondilatos G., Economidis P.S. 2005. Lessepsian migration of fishes to the Aegean Sea: First record of Tylerius spinosissimus (Tetraodontidae) from the Mediterranean, and six more fish records from Rhodes. Cybium 29: 347-354.

Corsini-Foka M., Economidis P.S. 2007. Allochthonous and vagrant ichthyofauna in Hellenic marine and estuarine waters. Mediterranean Marine Science. 8: 67-89.

Corsini-Foka M., Frantzis A. 2009. First documented record of imperial blackfish, Schedophilus ovalis (Actinopterygii: Perciformes: Centrolophidae), in the Aegean Greek waters. Acta Ichthyologica et Piscatoria 39: 47-49. DOI: 10.3750/AIP2009.39.1.09. 
Costa F. 1999. I pesci del Mediterraneo - stadi larvali e giovanili. [The fish of the Mediterranean-larvae and juveniles.] Grafoeditor, Messina. [In Italian.]

Costa F., Genovese L. 2009. I pesci batiali dello Stretto di Messina e zone viciniori. [Demersal fishes of the Strait of Messina and neighboring areas.] Consiglio Nazionale delle Ricerche, Instituto per l'Ambiente Marino Costiero, Maggio. [In Italian.]

Costa O.G. 1844. Fauna del Regno di Napoli ossia enumerazione di tutti gli animali che abitano le diverse regioni di questo Regno e le acque che le bagnano contenente la descrizione de' nuovi o poco esattamente conosciuti. [Fauna of the Kingdom of Naples; checklist of all the animals that inhabit various regions of this Kingdom and the surrounding waters with the description of new- or little known ones.] Dalla Stamperia di Azzolino e Compagno, Napoli. [In Italian.]

Eschmeyer W.N. (ed.) 1998. Catalogue of fishes. Vols. 1-3. California Academy of Sciences, San Francisco.

Filin A.A. 1989. [Comparative biological characteristics of Kroyer's lanternfish from north-eastern and north-western Atlantic.] Pp. 128-140. In: Bioresources of meso- and bathypelagial of the open part of the North Atlantic. Collected papers. PINRO, Murmansk. [In Russian.]

Filiz H., Akçinar S.C., Ulutürk E., Bayhan B., Taşkavak E., Sever T.M., Bilge G., Irmak E. 2007. New records of Bregmaceros atlanticus (Bregmacerotidae), Echiodon dentatus (Carapidae) and Nemichthys scolopaceus (Nemichthyidae) from the Aegean Sea. Acta Ichthyologica et Piscatoria. 37: 107-112. DOI: 10.3750/AIP2007.37.2.07.

Fricke R., Bilecenoglu M., Sari H.M. 2007. Annotated checklist of fish and lamprey species (Gnathostomata and Petromyzontomorphi) of Turkey, including a Red List of threatened and declining species. Stuttgarter Beiträge zur Naturkunde A 706: 1-169.

Froese R., Pauly D. (eds.) 2009. FishBase. [version 05/2009] http://www.fishbase.org.

Hulley P.A. 1984. Myctophidae. Pp. 429-438. In: Whitehead P.J.P., Bauchot M.-L., Hureau J.-C., Nielsen J., Tortonese E. (eds). Fishes of the North-eastern Atlantic and the Mediterranean. Vol. 1. UNESCO, Paris.

Kasapidis P., Peristeraki P., Tserpes G., Magoulas A. 2007. First record of Lessepsian migrant Lagocephalus sceleratus (Gmelin 1789) (Osteichthyes: Tetraodontidae) in the Cretan Sea (Aegean, Greece). Aquatic Invasions 2: 71-73. DOI: 10.3391/ai.2007.2.1.9.

Kobayashi K. 1958. Some lantern fishes from the North Pacific and Bering Sea. Japanese Journal of Ichthyology 7: 119-125.

Kubota T., Uyeno T. 1972. On the occurrence of the lanternfish Electrona rissoi in Japan. Japanese Journal of Ichthyology 19: $125-128$.

Labropoulou M., Papaconstantinou C. 2000. Community structure of deep-sea demersal fish in the North Aegean Sea (northeastern Mediterranean). Hydrobiologia 440: 281-296. DOI: 10.1023/A:1004199917299.

Lo Bianco (ed.) 1931-1956. Uova, larve e stadi giovanili de Teleostei. Fauna e flora del Golfo di Napoli. [Eggs, larvae and juvenile stages of Teleostei. Fauna and flora of the Golf of Naples.] Publicata dalla Stazione Zoologica di Napoli. 38. Monografia. G. Bardi/R. Friedlander \& Sohn, Roma/Berlin. [In Italian.]

Manzhirina G.P., Filin A.A. 1992. [Features of reproductive biology of Kroyer's lanternfish (Notoscopelus kroeyeri, Malm) (Myctophidae).] Pp. 219-238. In: Studies on bioresources of the North Atlantic. Collected papers. PINRO, Murmansk. [In Russian.]

Morales-Nin B., Maynou F., Sardà F., Cartes J., Moranta J., Massutí E., Company J., Rotllant G., Bozzano A., Stefanescu C., Can Liró. 2001. Size influence in zonation patterns in fishes and crustaceans from deep-water communities of the western Mediterranean. NAFO SCR Doc. 01/142. Serial No. N4536. NAFO Headquarter, Dartmouth.

Moreno-Amich R., Garcia-Berthou E. 1985. Addenda al catàleg de peixos del Mar Català de les colleccions de la Universitat Autònoma de Barcelona. Scientia Gerundensis 10: $57-63$.

Nafpaktitis B.G. 1975. Review of the lanternfish genus Notoscopelus (family Myctophidae) in the North Atlantic and the Mediterranean. Bulletin of Marine Science 25: 75-87.

Nafpaktitis B.G., Backus R.H., Craddock J.E., Haedrich R.L., Robison B.H., Karnella C. 1977. Family Myctophidae. Pp. 13-265. In: Fishes of the Western North Atlantic. Memoir Sears Foundation for Marine Research. No. 1, Pt. 7. Yale University, New Haven, CT.

Özaydin O., Leblebici S., Ulutürk E., Filiz H. 2007. First record of Epigonus constanciae (Giglioli, 1880), (deepwater cardinalfish) (Osteichthyes: Epigonidae), from Aegean Sea, Turkey. Acta Ichthyologica et Piscatoria 37: 91-94. DOI: 10.3750/AIP2007.37.2.04.

Özen Ö., Ayyıldız H., Tuncay D., Bilecenoglu M. 2009. First record of Gobius couchi (Pisces: Gobiidae) from the Aegean Sea. Zoology in the Middle East 47: 109-110.

Ozen O., Irmak E., Bilecenoglu M. 2007. Occurrence of Pomatoschistus minutus (Pallas, 1770) (Pisces: Gobiidae) along the north Aegean coast of Turkey. Annales, Series Historia Naturalis 17: 161-164.

Palomera I. 1983. Desarollo larvario de Notoscopelus elongatus elongatus (Costa, 1844) y Notoscopelus bolini Nafpaktitis, 1975. Investigacion Pesquera 47: 263-276.

Sabatés A. 1990. Distribution pattern of larval fish populations in the northwestern Mediterranean. Marine Ecology Progress Series 59: 75-82.

Sabatés A., Masó M. 1992. Unusual larval fish distribution pattern in a coastal zone of the western Mediterranean. Limnology and Oceanography 37: 1252-1260.

Sabatés A., Olivar M.P., Salat J., Palomera I., Alemany F. 2007. Physical and biological processes controlling the distribution of fish larvae in the NW Mediterranean. Progress in Oceanography 74: 355-376.

Shust K.V., Orlov A.M. 2003. [Prospects for exploitation of lanternfish stocks.] Rybnoe Hozâjstvo 2: 38-41. [In Russian.]

Tåning A.V. 1918. Mediterranean Scopelidae (Saurus, Aulopus, Chlorophthalmus and Myctophum). Report on the Danish Oceanographical Expeditions 1908-10 to the Mediterranean and Adjacent Seas. Vol. II. Biology. 
Tåning A.V. 1928. Synopsys of the scopelids in the North Atlantic. Videnskabelige Meddelelser fra Dansk Naturhistorisk Forening 86: 49-69.

Tåning A.V. 1932. Notes on scopelids from the Dana Expeditions. I. Videnskabelige Meddelelser fra Dansk Naturhistorisk Forening 94: 125-146.

Taşkavak E., Bilecenoglu M., Basusta N., Mater S. 2000. Occurrence of Pteragogous pelycus Randall, 1981 (Teleostei: Labridae) and Petroscirtes ancylodon Rüppel, 1938 (Teleostei: Blenniidae) at the eastern Mediterranean coast of Turkey. Acta Adriatica 41: 53-58.
Wienerroither R.M. 2005. Meso-and bathypelagic fishes of the Canary Islands: an annotated species list, species composition, and biogeographic distribution. Ph.D. Thesis. Paris Lodron University of Salzburg, Salzburg.

Received: 16 June 2009 Accepted: 29 September 2009 Published electronically: 10 December 2009 